\title{
Russian fund gets off the ground - at last
}

\begin{abstract}
Washington \& Moscow. The US Civilian Research and Development Foundation (CRDF), set up last August to fund joint projects between scientists in the United States and the countries of the former Soviet Union (FSU), last week put out its first call for proposals.

The CRDF now has $\$ 10$ million in hand, thanks to the efforts of the US government and the philanthropist George Soros, who settled a dispute about support for the nonprofit fund earlier this year (see Nature 375, $170 ; 1995)$. The foundation also has promises of $\$ 5$ million more from Russia, and a possible $\$ 1.5$ million from the Ukraine.

Only $\$ 6$ million of those funds will be used for this first round of competitive grants. Successful research teams will receive between $\$ 10,000$ and $\$ 80,000$ for a two-year grant period. Any area of civilian research and development will be considered for support, but projects with a commercial or entrepreneurial emphasis will be favoured, as will FSU researchers who formerly worked on defence projects.
\end{abstract}

All applications will be reviewed by CRDF panels of scientists and engineers, and the winners will be selected by next July.

Several factors distinguish the CRDF grants from previous aid programmes to Russian scientists, according to Peter Raven of the Missouri Botanical Garden, the chairman of the foundation's board of directors. First, although the grants are relatively modest, they represent the first US government money awarded for research in the FSU.

Second, the grants cover both basic and applied research, without any distinction being made between the two. And third, every team must include both an FSU scientist and a US scientist, a condition intended to build partnerships between researchers and foster intellectual communication.

Few pretend that the CRDF money will, on its own, be sufficient to save Russian science. Irving Lerch of the American Physical Society, which has taken an active role in fostering collaboration with FSU researchers, says that there are too many scientists looking for work, too much politi-

\section{Political muscle for French science}

Paris. Last week's surprise reshuffle of the French government brought the removal of both Elisabeth Dufourcq (RPR), the secretary of state for research, and Elisabeth Hubert (RPR), the health minister, as well as the demotion of François Fillon (RPR), previously minister for information technology, who becomes a junior minister responsible for the Post Office, Telecommunications and Space.

Dufourcq is replaced by François d'Aubert (UDF-PR), who was secretary of state for the budget

in the previous government. The move is widely seen in Paris as stemming less from unhappiness with Dufourcq - who despite her lack of political experience, was considered otherwise to be doing a reasonable D'Aubert: which way job - and more

from the need to find a new position for d'Aubert, who is said to have been in conflict in his previous post with the finance minister, Jean Arthuis (UDF-CDS).

It is too soon to predict d'Aubert's likely impact on research. But observers point out that he is a political heavyweight, being vice-president of the UDF group - one of the main groups that make up the conservative coalition headed by Alain Juppé, the prime minister - in the
National Assembly. D'Aubert's experience in the finance ministry could make him either an effective defender of research budgets, or alternatively an aggressive proponent of deep budgetary reforms of the research system.

Dufourcq and Hubert were two of eight women removed from the government in a reshuffle that reduced the total number of ministers and junior ministers from 41 to 32. The replacement of one of the shortestlived governments in recent history is aimed at reversing the plummeting popularity of Juppé and Jacques Chirac, the French president, by replacing the previous floundering government with a tighter and more experienced team.

The health ministry is absorbed within a super-ministry of employment and social affairs, under Jacques Barrot (UDF-CDS), whose main task will be to reduce the social security deficit. Hubert, a close ally of Chirac, was sacked for indiscretion and unreliability. Her health portfolio goes to a secretary of state, Hervé Gaymard (RPR).

The demotion of Fillon, who led the French delegation to last month's space ministers meeting of the European Space Agency (see Nature 377, 667-668; 1995), and was the cabinet minister responsible for research and universities in the previous government, follows his poor handling of plans to privatize France Telecom.

But the armed forces are said to have supported continuing the responsibilities of Fillon, who is a defence expert, for the space portfolio. cal infighting in Russia and too many economic and cultural hurdles for the problem to be solved overnight.

But Lerch says that the CRDF "can have a salutary impact if it's done cleverly, and if it makes some effort to coordinate with the other programmes going on worldwide", such as the European Union's INTAS (see Nature 375, 345; 1995) and the US Industry Coalition (USIC), funded by the Department of Energy, which will provide $\$ 35$ million to support collaboration with researchers in DoE laboratories.

Raven also admits that "the [CRDF] money is not going to go very far", given that there are 600,000 former-Soviet scientists and engineers in need of support. But he hopes the strategy of targeting commercially useful research will benefit FSU economies, and that these will in turn improve the situation for researchers in those countries.

The foundation's board will soon consider whether to create a separate, \$2-million grant programme limited to cooperation in industrial research and development. But Raven says that this is still unexplored territory, and that, whatever the board decides, the CRDF can be only a small player in the broad game of building East-West industrial partnerships.

The CRDF was first proposed in US legislation sponsored by Congressman George Brown of California, then-Senator $\mathrm{Al}$ Gore of Tennessee, and Senator Joseph Lieberman of Connecticut. The resulting authorization to create the CRDF was passed by the US Congress and signed into law in 1992.

The CRDF's initial funding comes from a $\$ 5$-million allocation from the Department of Defense's Nunn-Lugar programme, designed to promote the demilitarization of the FSU, and a matching \$5-million gift to the US National Science Foundation from Soros. Tony Reichhardt \& Carl Levitin

\section{Montreal wins bid for biodiversity centre}

London. Montreal in Canada has been chosen as the location of the secretariat of the UN Convention on Biological Diversity, signed at the Earth Summit in Rio de Janeiro in 1992. The decision was announced on Monday at the beginning of the second week of the annual conference of parties to the convention, which is being held in the Indonesian capital Jakarta.

Montreal was chosen in preference to Nairobi - which houses the headquarters of the United Nations Environment Programme - and Geneva, which is expected to continue to house the secretariat temporarily for a further year. The fourth candidate was Madrid, the Spanish capital. 